\title{
SERVICE DISTRIBUTION AND SATISFACTION TOWARD CUSTOMER LOYALTY
}

\author{
R. Agoes Kamaroellah ${ }^{1}$, Anis Eliyana ${ }^{2}$, Reza Mubarak ${ }^{3}$
}

${ }^{13}$ Faculty of Islamic Economics and Business, Institut Agama Islam Negeri Madura

\author{
J1. Raya Panglegur KM.4, Pamekasan and 69371, Indonesia \\ ${ }^{2}$ Management Department, Faculty of Economics and Business, Universitas Airlangga \\ Jalan Airlangga No. 4 - 6, Airlangga, Surabaya, East Java, Indonesia \\ 1agoes.kamaroellah.stain@gmail.com, ${ }^{2}$ anis.eliyana@,feb.unair.ac.id, \\ 33rezamubarak@iainmadura.ac.id
}

\begin{abstract}
Automated Teller Machines (ATMs) are a medium for financial transactions. This study investigates the impact of service distribution and service satisfaction on customer loyalty on ATM usage of the BRI Syariah Sub-Branch Office (KCP) Pamekasan. Data obtained from primary data in ATM user respondents' Form, the data analyzed by SEM with PLS approach. The calculation is carried out in two phases, the first-order phase, and the second-order phase. A validity and reliability test revealed that all three variables were valid and reliable in the firstorder phase. At the same time, the second-order phase was used, CFA, and Construct Reliability. Subsequently, an Inner Model test uncovered that the Service Distribution has no significant effect on Customer Loyalty. Contrastively, Service Satisfaction has a significant positive impact on customer loyalty. The goodness of Fit based on R-Square reveals that Service Distribution and Service Satisfaction can explain Service Loyalty at BRI Syariah KCP Pamekasan ATM very well.
\end{abstract}

Keywords: Customer Loyalty; Service Distribution; Service Satisfaction

\section{Introduction}

The era of globalization has a wide-ranging effect on the growth of the banking industry. Indonesia, which is well-known as a developing country, also undergoes the banking industry growth. The banking industry has a crucial role in developing the economic sector, supporting equitable development, increasing economic growth, and maintaining national stability in improving people's lives. As intermediary institutions, banks require the public's trust, especially their customers, to keep the banking industry's sustainability. The banking industry in Indonesia is getting bigger. It is indicated by the emergence of Islamic-based banks or sharia banks (Nofinawati, 2016).

Sharia banks are banks that operate the procedures based on Islamic practices, 
referring to the provisions of the Qur'an and the Hadith (Sumar'in, 2012). As a financial institution, Sharia Banks have the core business to provide financial services and some services related to the payment and circulation of money whose procedures are adjusted to Islamic principles. Sharia banks are established to promote and develop Islamic principles and traditions into financial and banking transactions. Sharia bank provides financial and investment products differently compared to those of conventional banks. From 1992 to 2005, Sharia bank rapidly and continuously grew. In 1992-1998, there was only one Sharia bank unit, but sharia banks in Indonesia had reached 20 companies in 2005 (Karim, 2013).

The amount of Sharia banks in Indonesia is significantly increasing, and it causes intense competition among them. The best way to maintain customers is to influence their customers, one of which is the marketing mix strategy of service distribution.

Building customer loyalty is an essential policy for the company. It is caused by the company that believes that customer loyalty is part of the company's strategy in dealing with competitors and connecting the company with the market (consumers). Customer loyalty is highly needed as an element in a competitive marketing strategy.
In dealing with more competitive market conditions, particularly, the company frequently aware that customer loyalty influences their future.

A study conducted by (Lam, Shankar, Erramilli, \& Murthy, 2004) provides an essential reference for this study. The present study investigates the relationship between customer satisfaction and customer loyalty. This study's results are expected to give a critical justification as a reference that customer satisfaction and customer loyalty have a positive relationship. Therefore, for some companies, customer loyalty is often identified as a guarantee for short-term and long-term advantages (Farris, Bendle, Pfeifer, \& Reibstein, 2010). Customer loyalty was derived from brand loyalty, reflecting customer loyalty to specific brands (Dharmmesta, 1999).

Interviews with employees of the BRI Syariah Sub-Branch Office (KCP) Pamekasan provided Information that the Automated Teller Machine (ATM) network of BRI Syariah has only 1 (one) unit serving a total of 5000 (five thousand) customers. The number of Automated Teller Machines (ATM) networks is not comparable to the number of customers. However, BRI Syariah customers can still conduct financial transactions efficiently through Automated Teller Machines (ATMs) of Bersama and Prima networks despite the need to pay the 
additional costs. Having only one unit ATM causes BRI Syariah customers' service distribution toward the availability of Automated Teller Machines (ATMs) is less optimal. Consequently, it will harm service satisfaction and will affect customer loyalty. Adding the number of Automated Teller Machines (ATMs) units is needed to meet the community's needs. If it is not immediately handled or neglected, the customers will save their money at another bank.

Research on the distribution of Automated Teller Machines (ATMs) service and customer satisfaction toward customer loyalty is necessary to investigate because of the high demand for banking services. Customer loyalty is an essential element of every Bank. Currently, Automated Teller Machines (ATM) services are used by almost all community members. People prefer to use Automated Teller Machines (ATMs) as a medium for financial transactions rather than visiting a bank office.

Advances in information technology led to the emergence of various internetbased business applications. BRI Syariah Pamekasan Branch Office has used internet applications to increase customer satisfaction and pay attention to the importance of ATM quality. There are no connection disruptions, and the availability of money in machines malfunction the ATMs. This research is related to service to customers with the use of an ATM. Although it is limited, it can provide satisfaction through SMS Banking and using an ATM and other banks to offer customers convenience in making transactions.

Some previous researches have been discussed this topic. The first research is studied by (Yulianto 2015). In his study, he found a significant correlation between ATM service quality and customer satisfaction in BNI Bank Pasuruan. Besides, Syaipullah (2011) also found a positive influence on ATM services' use to the customers' satisfaction in Bank Mandiri Ahmad Yani Pekanbaru Branch. Both studies are similar to this research in terms of the subject of the study. This research also explained the effect of ATM services on the customers' satisfaction. The difference is in the object being studied. This research studied phenomena in a Syariah bank, BRI Syariah KCP Pamekasan branch. Furthermore, the distribution and Loyalty are used as variables. This research also administered random Sampling with the number of respondents of 100 people, and it is analyzed by using Structural Equation Modelling (SEM) with Partial Least Square (PLS).

The purpose of this study is to measure the degree of the influence and the 
significance of the service distribution and satisfaction of Automated Teller Machines (ATMs) toward customer loyalty at BRI Syariah Sub-Branch Office $(\mathrm{KCP})$ Pamekasan.

\section{Literature Theory/ study}

A marketing mix is a tool for marketers consisting of various elements of a marketing program that needs to be considered so that the marketing strategy and positioning can be successfully done (Kasmir, 2014). The concept of a marketing strategy is related to selecting the offer types suitable for a particular market segment. A marketing mix is a combination of processes carried out by various companies in the marketing domain (Kasmir, 2004).

Distribution is the third marketing mix after the product and the price. Distribution in the banking industry is vital because it influences raising funds from the public and channeling it back. Distribution in service marketing is a service cycle that involves three interrelated channels. There are no goods moved in the context of distribution in service, but information transactions are mostly carried out through electronic media such as Automated Teller Machines (ATM).

Automated Teller Machines (ATM) is an electronic service system provided to customers using a computer to automatically perform various functions, which are usually performed by tellers (Ismail, 2018). People nowadays are increasingly active outside the home and demanding convenience in multiple ways. The existence of Automated Teller Machines (ATMs) is undoubtedly beneficial for the public in conducting bank-based financial activities. Consequently, many activities are carried out without time constraints. Factors related to services such as the speed of service delivery is the most effective way of maintaining the customers, so that convenience is the key to the marketing mix strategy of service distribution.

Marketing strategy is very dependent on customer evaluation and expectations. Therefore, the company's orientation is now emphasized on the quality of service and the value and satisfaction. Customer satisfaction is the customer's feelings after comparing the product's performance (results) with his/her expectations (Sumarni, 2011).

Customer satisfaction is the customer's responsibility for evaluating the perceived conformity between prior expectations and the actual performance of the product perceived after its use (Al Arif, 2010). Customer satisfaction is one of the secrets to the success of a business. Neglecting customer satisfaction can lead the business failure. Customer dissatisfaction causes customer disappointment, so that they look for 
alternatives to other similar products the alternative products.

There are three primary methods of service, namely; (1) Customers visit the service provider place, (2) Service providers come to the customer, (3) Services are conducted with long-distance transactions (Lovelock \& Wright, 2012).

Deciding on the location of service facilities for customers involves the considerations that differ from the review of choosing on the backstage elements' site. The cost, productivity, and labor access frequently serve as the main determinants. The key to deciding the location is customer service facilities, convenience, and preferences. Current location trends include mini shops, various retail venues with complementary service providers and are located in multipurpose facilities such as offices, hospitals, etc. Delivery times for some very responsive service providers have changed to service $24 / 7$ or 24 hours a day and seven days a week (Lovelock \& Wright, 2012).

Automated Teller Machine (ATM) is a machine that can automatically serve customers' needs at any time for 24 hours and seven days a week, including holidays. The presence of an Automated teller Machine (ATM) that serves 24 hours assists the people so that there is no economic activity hindered by bank office hours.
Services provided by Automated Teller Machine (ATM) include; Cash withdrawal, a service to order checkbooks and Transfer Form, a service to request a checking account, a service to find out or check customer account balances, and other services such as electricity and telephone payments (B. Kasmir \& Lainnya, 2014).

Other benefits that can be provided by Automated Teller Machines (ATMs) are; (1) Practical and efficient in its services, (2) ATM is relatively easy operated, (3) Provide 24 hours service including holidays, (4) Guaranteeing security and privacy, (5) Allowing to withdraw cash more than once a day, (6) available in various strategic locations (S. Kasmir, 2014).

Satisfaction is the level of feelings perceived after comparing the product's performance (results) with the expectations (Sumarni, 2011). The customer is a person who is related to or registered as a client of a bank (in financial activities) (Kamus, 2007).

Four methods used by companies to measure customer satisfaction are described as follows; (1) Complaints and Suggestions, (2) Ghost Shopping (Mystery Shopping), (3) Lost Customer Analysis, (4) Customer Satisfaction Survey (Tjiptono \& Chandra, 2016).

Loyalty is the customer's attitude in determining the preference to keep using 
certain products or services. The perspective in determining the choice also aims to commit and repurchase to the company (Foster and Cadogan, 2000). Foster and Cadogan (2000) argued that customer loyalty would evoke the customer behavior and actions such as; (1) Customer's behavior that provides recommendations to encourage others to purchase or use the products, (2) Customers conduct a transaction or use all forms of services offered by banks, (3) Customers make the Bank as the first option in using financial services, (4) Word of mouth is the customer's behavior to talk over good things related to the product provided by the Bank to others.

Distribution is the third marketing mix after product and price. Distribution in the banking business is essential. The distribution strategy influences collecting funds from the community and channeling it back to the community (Al Arif, 2010). Nine indicators form the service distribution exogenous variable (X1)

Satisfaction is the level of a person's feelings after comparing the perceived product performance (results) with expectations (Sumarni, 2011). A customer is a person who usually deals with or becomes a bank customer (in financial terms) (Kamus, 2007). Five indicators form the exogenous variable of Customer Service Satisfaction (X2).

Loyalty is the customers' attitude in determining their choice to continue using a company's products or services. The philosophy of determining these choices is to make commitments and repurchase at the company (Foster \& Cadogan, 2000). Four indicators form endogenous variables of Customer Loyalty (Y1).

\section{Method}

\section{Research Design}

This study employed a quantitative research method.

Latent Variables used in this study are Service Distribution $\left(\mathrm{X}_{1}\right)$, Customer Service Satisfaction $\left(\mathrm{X}_{2}\right)$, and Customer Loyalty $\left(\mathrm{Y}_{1}\right)$.

Distribution is the third marketing mix after products and prices. Distribution in the banking industry is crucially important. Distribution strategy influences collecting funds from the public and channeling it back to the public (Al Arif, 2010). Exogenous Variable of Service Distribution (X1) was formed by nine indicators presented in Table 1. 
Table 1.

Indicators of Service Distribution

\begin{tabular}{|c|c|}
\hline SYMBOL & INDICATORS \\
\hline $\mathrm{X}_{1.1}$ & $\begin{array}{l}\text { ATM of BRI Syariah located in a } \\
\text { strategic place }\end{array}$ \\
\hline $\mathrm{X}_{1.2}$ & $\begin{array}{l}\text { ATM of BRI Syariah located in } \\
\text { the center of Pamekasan }\end{array}$ \\
\hline $\mathrm{X}_{1.3}$ & $\begin{array}{l}\text { Transportation to ATM of BRI } \\
\text { Syariah is easily accessed. }\end{array}$ \\
\hline $\mathrm{X}_{1.4}$ & $\begin{array}{l}\text { Providing broad networks and } \\
\text { being wide-spread so that the } \\
\text { transaction process can achieve to } \\
\text { the destination place. }\end{array}$ \\
\hline $\mathrm{X}_{1.5}$ & $\begin{array}{l}\text { The availability of several ATM } \\
\text { units of BRI Syariah is sufficiently } \\
\text { adequate. }\end{array}$ \\
\hline $\mathrm{X}_{1.6}$ & $\begin{array}{l}\text { ATM of BRI Syariah guarantees } \\
\text { the availability of cash in the } \\
\text { machine }\end{array}$ \\
\hline $\mathrm{X}_{1.7}$ & $\begin{array}{l}\text { ATM of BRI Syariah gains } \\
\text { infrequent trouble }\end{array}$ \\
\hline $\mathrm{X}_{1.8}$ & $\begin{array}{l}\text { Easy to operate and not } \\
\text { complicated }\end{array}$ \\
\hline $\mathrm{X}_{1.9}$ & $\begin{array}{l}\text { ATM of BRI Syariah has rarely } \\
\text { queued }\end{array}$ \\
\hline
\end{tabular}

Table 2.

Indicator of Customer Satisfaction

\begin{tabular}{|l|l|}
\hline $\begin{array}{l}\text { SYMB } \\
\text { OL }\end{array}$ & INDICATORS \\
\hline $\mathrm{X}_{2.1}$ & $\begin{array}{l}\text { I feel satisfied and continuously be } \\
\text { the customer of ATM of BRI } \\
\text { Syariah. }\end{array}$ \\
\hline $\mathrm{X}_{2.2}$ & $\begin{array}{l}\text { I am satisfied with the products and } \\
\text { services provided by the ATM of } \\
\text { BRI Syariah. }\end{array}$ \\
\hline $\mathrm{X}_{2.3}$ & $\begin{array}{l}\text { I tell the good things about the ATM } \\
\text { of BRI Syariah to other people. }\end{array}$ \\
\hline $\mathrm{X}_{2.4}$ & $\begin{array}{l}\text { I recommended the ATM of BRIS } \\
\text { Syariah to family and colleagues. }\end{array}$ \\
\hline $\mathrm{X}_{2.5}$ & $\begin{array}{l}\text { If I need financial service, I will } \\
\text { choose the products of BRI Syariah. }\end{array}$ \\
\hline
\end{tabular}

\section{Population and Sample}

This study's population is all customers of BRI Syariah Sub-branch (KCP) Pamekasan who use Automated Teller Machines (ATMs) with a total of 5,000 customers. 
The sampling technique used in this study is simple random Sampling (Incidental Sampling). Random Sampling is a sampling technique based on coincidence; that is, everyone who meets a researcher can be recruited as the samples if it is suitable with the criteria of a source of data.

In calculating the sample size, the Slovin formula is conducted as follows:

$$
n=\frac{N}{1+N e^{2}}
$$

Note:

$\mathrm{N}=$ number of population

$\mathrm{n}=$ number of sample

$\mathrm{e}=$ error tolerance level

This study used primary data sourced from the sample responses to statements relating to service distribution, service satisfaction, and customer loyalty toward the Automated Teller Machine (ATM) service of BRI Syariah sub-branch Pamekasan. The data collected used a questionnaire distributed directly by researchers to respondents. The number of questionnaires distributed was 100 questionnaires, with a return rate of $100 \%$.

The data analysis method used in this research was the Structural Equation Modeling (SEM) analysis with Partial Least Square (PLS) approach. The calculation was carried out in two phases, namely the firstorder phase and the second-order phase. Both phases tested Validity and Reliability.
In the first-order phase, the validity and reliability test was carried out using Product Moment Correlation and Cronbach Alpha assisted by SPSS 20 software. Meanwhile, in the second-order phase, the validity test used Confirmatory Factor Analysis (CFA). The reliability test used Composite Reliability and Average Variance Extracted (AVE), and the Inner Model Test was performed using the SMART-PLS software.

\section{Discussion}

\section{Results}

\section{First Order Phase}

The validity test was calculated using the Product Moment Correlation, which aimed to determine whether the questionnaire questions are quite representative. Meanwhile, the reliability test was computed using Cronbach Alphabet, which intended to present the instrument's nature (in this study, the device used was a questionnaire). It tested whether the questionnaire was sufficiently accurate, stable, and consistent in measuring an indicator.

From the significance probability, the validity test results on the Service Distribution $\left(\mathrm{X}_{1}\right)$ represented by the nine indicators that have been formed are that all hands are valid, and no needles are excluded. The Results are Significance value (2-tailed) at the 0.01 level of each 
question from the first question $\left(\mathrm{X}_{1.1}\right)$ to the ninth question $\left(\mathrm{X}_{1.9}\right)$ with the same total score of 0.000 . It can be concluded that there is a significant relationship between each question from the first question $\left(\mathrm{X}_{1.1}\right)$ to the ninth question $\left(\mathrm{X}_{1.9}\right)$ with a total score.

Meanwhile, the reliability test results on Service Distribution $\left(\mathrm{X}_{1}\right)$ for valid indicators show that the Cronbach Alpha reliability coefficient is 0.819 . Therefore, this questionnaire is reliable. Moreover, to find out the reliability value of each reliable indicator can be done by comparing Cronbach Alpha if items Deleted with Cronbach Alpha. If Cronbach Alpha's value if Deleted items is higher than Cronbach Alpha, it means that the thing is unreliable.

From the significance probability, the validity test results on Customer Satisfaction $\left(X_{2}\right)$ represented by the five indicators formed are that all indicators are valid, and no indicators are excluded. The Results are the Significance value (2-tailed) at the 0.01 level of each question from the first question $\left(\mathrm{X}_{2.1}\right)$ to the fifth question $\left(\mathrm{X}_{2.5}\right)$ with the same total score of 0.000 . it can be concluded that there is a significant relationship between each question questions from the first question $\left(\mathrm{X}_{2.1}\right)$ to a fifth question $\left(\mathrm{X}_{2.5}\right)$ with a total score.

Meanwhile, the reliability test results on Customer Satisfaction $\left(\mathrm{X}_{2}\right)$ for valid indicators show that the Cronbach Alpha reliability coefficient is 0.875 , and this value is higher than 0.6. Therefore, this questionnaire is reliable. Moreover, to find out the reliability value of each reliable indicator can be done by comparing Cronbach Alpha if items Deleted with Cronbach Alpha. If Cronbach Alpha's value if Deleted items is higher than Cronbach Alpha, it means that the thing is unreliable.

From the significance probability, the validity test results on Customer Loyalty $\left(Y_{1}\right)$ represented by the four indicators that have been formed are that all hands are valid, and no indicators are excluded. The Results are the Significance value (2-tailed) at the 0.01 level of each question from the first question $\left(\mathrm{Y}_{1.1}\right)$ to the fourth question $\left(Y_{1.4}\right)$ with the same total score of 0.000 . it can be concluded that there is a significant relationship between each question questions from the first question $\left(Y_{1.1}\right)$ to the fifth question $\left(\mathrm{Y}_{1.4}\right)$ with a total score.

Meanwhile, the reliability test results on Customer Loyalty $\left(\mathrm{Y}_{1}\right)$ for valid indicators show that the Cronbach Alpha reliability coefficient is 0.880 , and this value is more significant than 0.6 . Therefore, this questionnaire is reliable. Moreover, to find out the reliability value of each reliable indicator can be done by comparing Cronbach Alpha if items Deleted with Cronbach Alpha. If Cronbach Alpha's value if Deleted items is higher than Cronbach 
Alpha, it means that the thing is unreliable.

\section{Second-Order Phase}

\section{Convergent Validity}

This calculation was carried out to determine the validity of indicator variables by finding out the indicators' convergent validity values in the model. Each indicator in the model must complete convergent validity by finding out the factor loading value greater than 0.5 (Dewi \& Nuzuli, 2017). If each hand has a factor loading value greater than 0.5 , it can proceed to the next analysis stage. However, suppose each indicator does not have a factor loading value greater than 0.5 . In that case, a reduction should be made for hands that have a convergent validity value that is less than 0.5 by doing further iterations until a factor loading value for each indicator is more significant than 0.5 . The latent variables that will be tested accordingly are Service Distribution $\left(\mathrm{X}_{1}\right)$, Service Satisfaction $\left(\mathrm{X}_{2}\right)$, and Service Loyalty $\left(\mathrm{Y}_{1}\right)$ variables.

Exogenous Variable of Service Distribution $\left(\mathrm{X}_{1}\right)$ is formed by nine indicators, namely Strategic Location $\left(\mathrm{X}_{1.1}\right)$, Located in the City Center $\left(\mathrm{X}_{1.2}\right)$, Transportation Access $\left(\mathrm{X}_{1.3}\right)$, Broad Network $\left(\mathrm{X}_{1.4}\right)$, Quantity $\left(\mathrm{X}_{1.5}\right)$, Availability of Cash $\left(\mathrm{X}_{1.6}\right)$, Infrequent Trouble $\left(\mathrm{X}_{1.7}\right)$, Easy to Use $\left(\mathrm{X}_{1.8}\right)$, and Rarely Queued $\left(\mathrm{X}_{1.9}\right)$. Therefore, to determine whether Service
Quality $\left(\mathrm{X}_{1}\right)$ is a latent variable. The confirmatory factor analysis results assisted by the Smart PLS program can be seen in Figure 1.

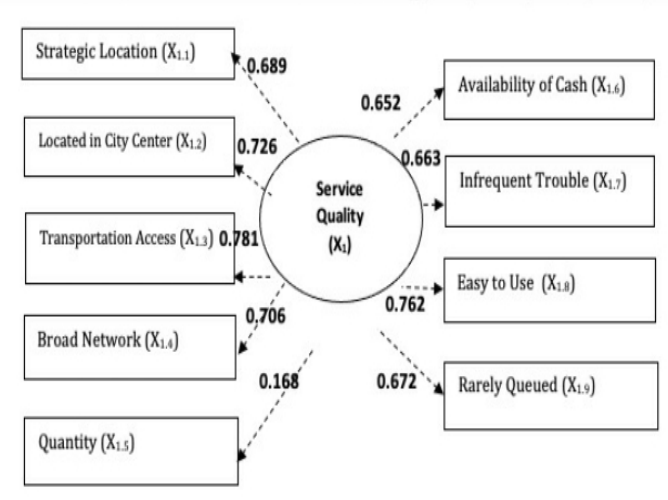

Figure 1. Convergent Validity of Indicators of Service Distribution Variable $\left(X_{1}\right.$

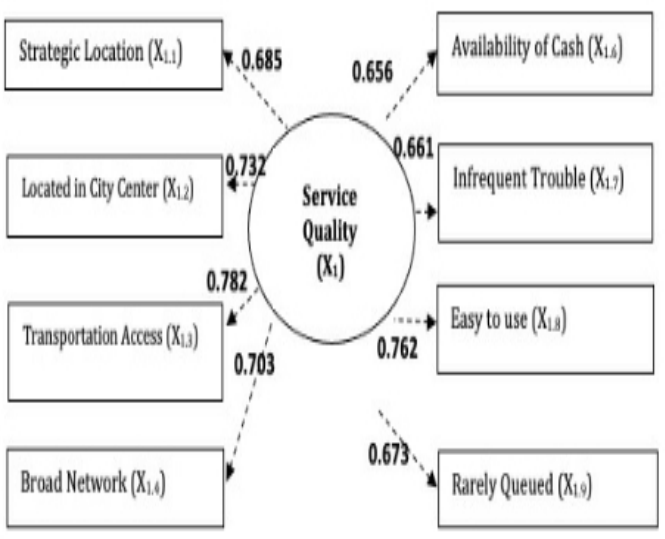

Figure 2. Convergent Validity of Variable X1 without Indicator X1.5

Based on Figure 1, that each indicator has a factor loading value $>0.5$ except the Quantity indicator $\left(\mathrm{X}_{1.5}\right)$, which has a convergent validity value of 0.167 , so that the Quantity $\left(\mathrm{X}_{1.5}\right)$ is invalid as an indicator of Service Distribution. It means that the other indicators are validated to indicate the Service Distribution variable $\left(\mathrm{X}_{1}\right)$. Therefore, these indicators can be accepted as a measure of the Service Distribution variable $\left(\mathrm{X}_{1}\right)$. 
The calculation performed on the convergent validity of the variable $\mathrm{X}_{1}$ without involving the Quantity indicator $\left(\mathrm{X}_{1.5}\right)$ so that the results obtained are shown in Figure 2. Based on Figure 2, each hand has a loading factor value $>0.5$. It means that the indicators are validated to be indicators of the Service Distribution variable $\left(\mathrm{X}_{1}\right)$, and all these indicators can be accepted as the measure of the Service Distribution variable $\left(\mathrm{X}_{1}\right)$.

Subsequently, a factor loading test was conducted on each indicator with the bootstrap sample; all indicators provide a Statistical Value of T, which is greater than 1.96 for the bootstrap sample $(\mathrm{n}=200)$. Therefore, these indicators are valid. The indicator that has the highest factor loading value is Transportation Access $\left(\mathrm{X}_{1.3}\right)$ with 0.782, followed by Easy to Use $\left(\mathrm{X}_{1.8}\right)$ with 0.762 and Located in the City Center $\left(\mathrm{X}_{1.2}\right)$ with 0.732 .

The exogenous variable of Service Satisfaction $\left(\mathrm{X}_{2}\right)$ is formed by five indicators, namely Loyal Attitude $\left(\mathrm{X}_{2.1}\right)$, Satisfaction Attitude $\left(\mathrm{X}_{2.2}\right)$, Good Impression $\left(\mathrm{X}_{2.3}\right)$, Recommendation $\left(\mathrm{X}_{2.4}\right)$, and Main Option $\left(\mathrm{X}_{2.5}\right)$. The results of the loading factors for each indicator in Figure 3.

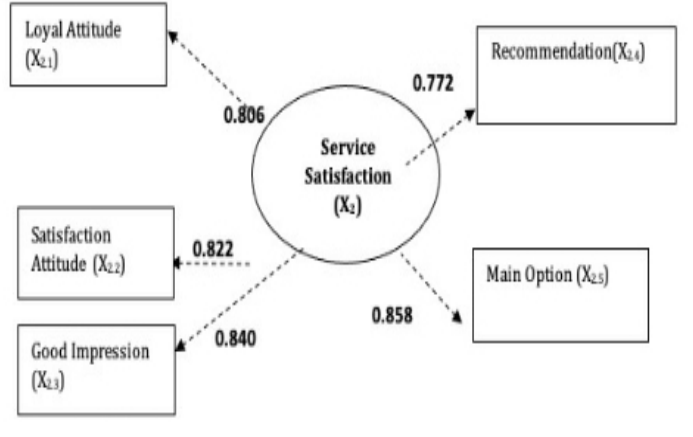

Figure 3. Convergent Validity of Indicators of Service Satisfaction Variable $\left(X_{2}\right)$

Based on Figure 3, each indicator has a factor loading value $>0.5$. It means that all of the indicators are validated as the Service Satisfaction variable $\left(\mathrm{X}_{2}\right)$; all indicators provide a Statistical value of $\mathrm{T}$ are more significant than 1.96 for the bootstrap sample $(n=200)$; therefore, that the hands are valid.

The indicator which has the highest factor loading value is the Main Option $\left(\mathrm{X}_{2.5}\right)$ with a factor loading value of 0.858 , followed by a Good Impression $\left(\mathrm{X}_{2.3}\right)$ with 0.840 and a Satisfaction Attitude $\left(\mathrm{X}_{2.2}\right)$ with 0.822 .

Then, the Endogenous Variable of Service Loyalty $\left(\mathrm{Y}_{1}\right)$ is formed by four indicators, namely Continuity $\left(\mathrm{Y}_{1.1}\right)$, Recommendations $\left(\mathrm{Y}_{1.2}\right)$, Main Option ( $\left.\mathrm{Y}_{1.3}\right)$, and Loyal Attitude ( $\left.\mathrm{Y}_{1.4}\right)$. The result of the loading factor of each indicator in Figure 3. 


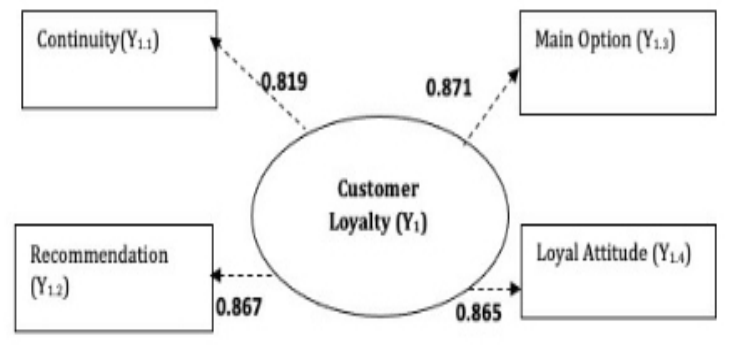

Figure 4.

Convergent Validity of Indicators of Service Loyalty Variable $\left(Y_{1}\right)$

Based on Figure 4, that each indicator has a factor loading value $>0.5$. It means that all indicators are validated as the Service Loyalty variable $\left(\mathrm{Y}_{1}\right)$. All latent variables' indicators provide a statistical significance of $\mathrm{T}$, which is greater than 1.96 for the bootstrap sample $(\mathrm{n}=200)$; therefore, these indicators are valid.

The indicator that has the highest factor loading value is the Loyal Attitude (Y.4) with 0.919 , followed by the Main Option ( $\left.\mathrm{Y}_{1.3}\right)$ with 0.896 and Continuity $\left(Y_{1.1}\right)$ with 0.853.

\section{Second-Order Reliability Test}

This phase's reliability test was conducted in two ways. Namely, Composite Reliability and Average Variance Extracted (AVE). Composite Reliability shows an excellent value if the value $>0.6$. AVE value is declared outstanding if the AVE value is more significant than 0.5. Calculating AVE aims to establish that the latent variable has a good discriminant validity value.
The composite Reliability indicators, which measure the latent variables of Service Quality $\left(\mathrm{X}_{1}\right)$, Service Satisfaction $\left(\mathrm{X}_{2}\right)$, and Service Loyalty $\left(\mathrm{Y}_{1}\right)$, have a Composite Reliability value which more than 0.6 . Thus, the three research variables can be declared as reliable variables.

Based on the AVE values, the indicators that measure the latent can be inferred have a good discriminant validity value because it has an AVE value that is more than 0.5 . It means that all indicator blocks which measure all latent variables are stated reliable.

\section{Inner Model Test}

The structural model test (inner model) is identified through the results of the structural path coefficient. The results of the path coefficient answer the hypothesis formulated as follows:

$\mathrm{H}_{1}$ : Service Distribution has significantly influenced the Loyalty Service of ATM provided by BRI Syariah in Pamekasan.

$\mathrm{H}_{2}$ : Service Satisfaction has significantly influenced the Loyalty Service of ATM provided by BRI Syariah in Pamekasan. 


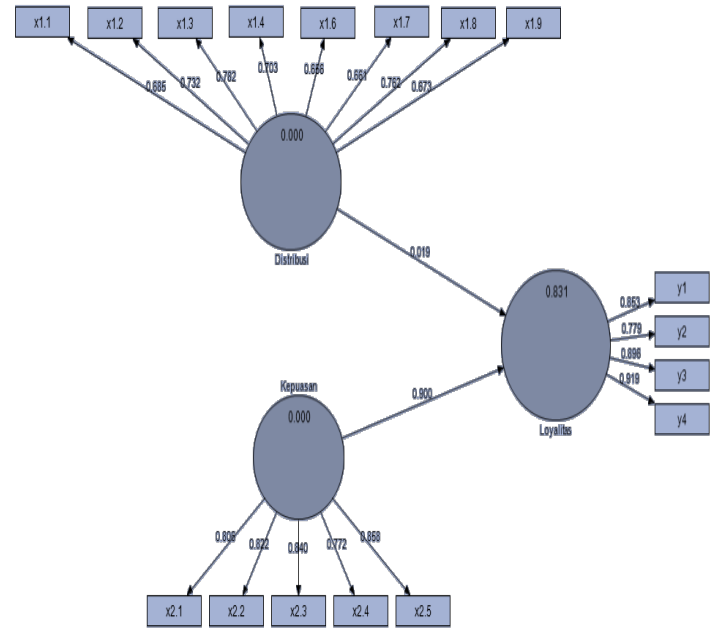

Figure 5. Path Diagram of Structural Equation Model

Service Distribution $\left(\mathrm{X}_{1}\right)$ has no influence and is not significant to Service Loyalty $\left(\mathrm{Y}_{1}\right)$. The path coefficient, which shows a positive at 0.019 with a Statistical value of $\mathrm{T}$ is 0.071 , is smaller than $\mathrm{T}$-table (1.96). Thus, the results of this study prove that Hypothesis 1 is rejected. Moreover, Service Satisfaction $\left(\mathrm{X}_{2}\right)$ has a positive and significant influence on Service Loyalty $\left(Y_{1}\right)$. The path coefficient shows a positive at 0.900 with a Statistical value of $\mathrm{T}$ of 19.270, which is greater than the T-table (1.96). Thus, Service Satisfaction $\left(\mathrm{X}_{2}\right)$ has a direct effect on Service Loyalty $\left(\mathrm{Y}_{1}\right)$ with a value of 0.900, which means that if Service Satisfaction value $\left(\mathrm{X}_{2}\right)$ increases, it will increase Service Loyalty (Y1) with the value of 0.900 . The results of this study prove that Hypothesis 2 is accepted.

With the appropriate model, each path coefficient can be interpreted. The path coefficients are hypotheses in this study, which can be presented in the following structural equation.

$$
Y_{1}=0.019 X_{1}+0.900 X_{2}
$$

The complete model test results, which are assisted by the SmartPLS program, can be interpreted from the RSquare values that describe a model's goodness-of-fit. The R-Square value is supposed to be greater than zero.

The contribution or proportion of Service Quality $\left(\mathrm{X}_{1}\right)$ and Service Satisfaction $\left(\mathrm{X}_{2}\right)$ in explaining variations around Service Loyalty (Y1) is 0.831 or $83.1 \%$. The R-square value shows that the $\mathrm{R}$-square value is greater than zero. It means that this research model completes the requirements of Goodness of Fit.

The present study, which investigates the effect of Service Distribution $\left(\mathrm{X}_{1}\right)$ and Service Satisfaction $\left(\mathrm{X}_{2}\right)$ on Service Loyalty $\left(\mathrm{Y}_{1}\right)$, utilizes the previous research as a reference to enrich the theory in this domain. After reviewing some literature, there are minimal studies conducted to investigate this topic. However, three previous studies are presented as references to enrich the literature review of this present study.

Soffan Arif conducted the first research. This study revealed some findings. Those are (1) Variables of assurance $\left(\mathrm{X}_{1}\right)$, Reliability $\left(\mathrm{X}_{2}\right), \quad$ responsiveness $\left(\mathrm{X}_{3}\right)$, tangible $\left(\mathrm{X}_{4}\right)$, and empathy $\left(\mathrm{X}_{5}\right)$ 
individually (partially) has a significant effect on customer satisfaction (Y) of the customers of ATM provided by BNI at PT. Swadharma Sarana Informatika Pasuruan; (2). Variables of $\mathrm{X} 1, \mathrm{X} 2, \mathrm{X} 3, \mathrm{X} 4$, and $\mathrm{X} 5$ (assurance, Reliability, responsiveness, tangible, and empathy) simultaneously have a significant effect on customer satisfaction (Y) of the customers of ATM provided by BNI at PT. Swadharma Sarana Informatika Pasuruan; and (3). The significance value of the responsiveness variable (X3) is higher than that of the assurance variable (X1), Reliability (X2), tangible (X4), and empathy (X5) and found that the responsiveness variable (X3) is the dominant variable that affects customer satisfaction (Y) of the customers of ATM provided by BNI at PT. Swadharma Sarana Informatika Pasuruan (Arif, 2012).

The previous study's similarity with the present study is that both studies investigate the Automated Teller Machine (ATM) and customer satisfaction. However, the participants of both studies are different. The previous research involved the customers of BNI Pasuruan, and the sampling technique implemented was the Purposive Sampling method with interview and questionnaire were utilized as the data collection technique. The previous study investigated the management service quality of Automated Teller Machines (ATM) and customer satisfaction.

Syaipullah conducted the second study". This result uncovered that the six independent variables simultaneously could explain and contribute to the dependent variable with $54.3 \%$. In contrast, the remaining $45.7 \%$ could be explained by variables not examined in this study. (3) The F value obtained was 18,421 , which was higher than the F-table (2.31). Thus, the hypothesis formulated that using an ATM card could enhance customer satisfaction (4) The results of the Partial test (t-test) of the six independent variables were Cash withdrawal (4,659), Cash deposits $(2,301)$, Purchases (2,334), Cash transfers (1,995), Payments (2,245), and Expenditures $(3,715)$. Therefore, the six variables influenced the customer satisfaction interpreted by the t-value, which higher than the $\mathrm{T}$ table $(1,984)$. (5) The results of each variable's description with three questions, with the research variable the advantages of the ATM card which consists of cash withdrawals, cash deposits, purchases, cash transfers, payments, and expenditure can be inferred from the participants' responses which answered very satisfied. It means that the participants were exceedingly happy with the advantages of the ATM cards and the services provided by Bank Mandiri 
Branch Ahmad Yani Pekanbaru (Syaipullah, 2011).

The previous study's similarity with the present study is that both studies investigate the Automated Teller Machine (ATM) and customer satisfaction. However, the participants of both studies are different. The previous research involved the customers of Bank Mandiri branch Ahmad Yani Pekanbaru and the sampling technique used was the Random Sampling method. The last study investigated the advantage of ATM cards and Bank Mandiri branch Ahmad Yani Pekanbaru 's customer satisfaction.

Tri Yulianto conducted the third research. This study concluded that (1). The results of the t-test revealed that the service quality variable had a significant effect on customer satisfaction due to the significance value (p-value) obtained was 0,000 , which was smaller than 0.05 . The confidence variable significantly impacted customer satisfaction due to the significance value (pvalue) received was 0,010 , which was smaller than 0.05 . (2) The F test results uncovered that F-value $>$ F-table $(26,396>$ 4.00) interpreted that $\mathrm{Ho}$ is rejected. It means that the service quality variables (X1) and confidence (X2) simultaneously significantly influenced customer satisfaction. (3) The coefficient of determination (R2) was obtained that the $\mathrm{R}$ square (R2) value was 0.339 . It means that the variations in customer satisfaction variables could be explained by service quality variables (X1) and confidence (X2) with $33.9 \%$. In comparison, the remaining $66.1 \%$ could be explained by other variables outside the model (Yulianto, 2015).

The previous study's similarity with the present study is that both studies investigate the Automated Teller Machine (ATM) and customer satisfaction. However, the participants of both studies are different. The previous research involved BRI customers, and the sampling technique implemented was the Purposive Sampling method with the questionnaire was utilized as the data collection technique. The previous study investigated Automated Teller Machines (ATM) service quality toward customer satisfaction (a BRI case study).

The present study is a study entitled "The Impact of Service Distribution and Satisfaction toward Customer Loyalty on Automated Teller Machines (ATM) of BRI Syariah Sub-Branch Office Pamekasan." The partial testing ( $\mathrm{t}$-test) revealed that the Service Distribution variable (X1) of the Automated Teller Machine (ATM) did not have a significant effect on the Service Loyalty of BRI Syariah. And the coefficient was 0.071 and the t-value obtained was 0.071which was lower than the t-table 
(1.96). Then, the partial test (t-test) revealed that the Service Satisfaction variable (X2) of the Automated Teller Machine (ATM) had a significant effect on the Loyalty Services BRI Syariah. an the coefficient was 0.071 and t-value (19.27) $>$ t-table (1.96).

The present study's similarity with the previous studies is that these studies investigate the Automated Teller Machine (ATM) and customer satisfaction. However, the present study's differences with the earlier studies are the participants, Distribution and Customer Loyalty variables, sampling technique, and data analysis. The present study recruited the customers of BRI Syariah sub-branch office (KCP) Pamekasan as the participants. The sampling technique implemented was the Incidental Sampling method. Random Sampling is a sampling technique based on coincidence; that is, everyone who meets a researcher can be recruited as the samples if it is suitable with the criteria of a source of data. The questionnaire was utilized as the data collection technique. One hundred participants were recruited as the samples of the study. The data were analyzed using Structural Equation Modeling (SEM) with Partial Least Square (PLS) approach. The present study investigates the Distribution and Service Satisfaction towards the Loyalty of the customer of the Automated Teller
Machine (ATM) provided by BRI Syariah Sub-Branch Office Pamekasan.

Marketing is the study of an exchange process that analyzes how transactions are initiated, motivated, and assumed (Sumarni, 2011). Marketing is a social process in which individuals and groups obtain what they need and want by creating, offering, and exchanging valuable products freely with others (Kotler, 2018).

The concept of marketing is a philosophy of business that evokes to challenge previous ideas. The marketing concept relies on three principal foundations, namely; (1) Customer-oriented marketing, coordinated marketing, and profitability, (2) The images of the insideout marketing concept, (3) The idea of outside-in marketing (Kotler, 2018).

Distribution is the third marketing mix after products and prices. Distribution in the banking industry is very crucial. Distribution strategy influenced collecting funds from the community and channeling it back to the community (Al Arif, 2010). Distribution in a manufacturing company's marketing moves the goods through physical channels to distributors and retailers to sell for the end consumers.

Distribution in the general service cycle involves three interrelated streams and answers the questions about what will be distributed. These streams are: (1) the flow 
of Information and promotion; distributing the Information and promotional material related to the service offered. The aim is to encourage customers to buy these services. (2) the flow of negotiation; achieving an agreement in terms of service features and configuration, along with the offers' requirements, can be achieved. The aim is to sell the right to use a service. (3) The flow of products; many benefits, especially those involving human beings or ownership, require the physical facilities for service delivery (Lovelock \& Wright, 2012).

Examining the distribution can employ the following indicators;

Transportation System, (2) Product Availability, (3) Waiting Time (Riyanto, 2015).

Service Distribution $\left(\mathrm{X}_{1}\right)$ does not affect and is not significant on Service Loyalty $\left(\mathrm{Y}_{1}\right)$. It can be identified from the path coefficient, which is positive at 0.019 with a Statistical of T-value is 0.071 , which is smaller than T-table $=1.96$. Thus, the result of this study concludes that Hypothesis 1 is not accepted.

The company's excellent customer satisfaction can be generated in which the customers perceive its performance beyond the desired expectations for a company's services. Customer satisfaction is not achieved easily. People are now getting smarter and starting to realize their rights.
This can be solved by establishing a good business strategy to guarantee the sustainability of the Bank. If customers begin to obtain satisfaction, the services should be improved continuously because the banks work with the principle of confidentiality. Thus, the value established is significant. The excellent value will make the customers obtain satisfaction, and eventually, the customers turn to be the loyalist (Supriyanto, 2003).

Service Satisfaction (X2) has a positive and significant effect on Service Loyalty (Y1). From the path coefficient, which is positive at 0.900 , a Statistical of Tvalue is 19.270 , which is greater than Ttable (1.96). Thus, Service Satisfaction (X2) has a direct effect on Service Loyalty (Y1) of 0.900 , which means that any increase in Service Satisfaction (X2) will increase Service Loyalty (Y1) by 0.900 . The result of this study revealed that Hypothesis 2 is accepted.

The quality of a bank's services does not determine the Loyalty of the customers. Customer loyalty to a bank's benefit is not always equal to the Bank's services' quality. The Bank, which is considered capable of providing the best quality of service, is BRI Syariah.

Some reasons for the dissatisfaction are (1) Gap between expectations and reality, meaning that the expected benefits 
or results do not match with the reality of what is obtained by consumers, (2) Services during the process of using the products are unsatisfactory, (3) The attitude of the staff is less satisfactory, meaning that the employee attitude disappoints the customers, (4) The atmosphere and physical conditions of the environment are not supportive; for example, the layout of buildings that are not neatly arranged, (6) Costs are too high; for example, monthly administrative costs are too high and higher than other banks or profit-sharing levels that are too burdensome for the customers, (7) Promotion/advertisement is too grandiose which does not correspond to the reality (Alma, 2007).

The customer satisfaction provided by the Bank will impact very broadly to increase bank profits. If the customer is satisfied with the purchase of bank services, the customer will be loyal, repurchase, or continuously use it and recommend the products to others (Kasmir, 2004).

Accordingly, there are several customer loyalty levels, starting from the lowest to the highest level (Aaker, David A., 1996). Those are: (1) Switches, buyers are not loyal at all, are not interested in company brands, any brands are considered adequate, are easily change in purchasing any brands, and are too considerate to the price of products, (2) Habitual buyers, buyers who are satisfied with the product / are habitual, so there is no constraint to switch to other brands, are not experiencing dissatisfaction, (3) Satisfied buyers, are buyers who satisfied, but they are liable to the switching costs, costs in time, money or performance risks regarding switch the brands, (4) Like the brand, buyers who like the brand, consider the brand as a friend, (5) Committed buyers, are loyal customers, have pride in finding out or becoming customers of a brand (Aaker, 1996).

Based on the research result regarding the distribution of automated teller machines (ATM) services and customer service satisfaction with customer loyalty, test results are likely to contribute to the following implications.

1. The theoretical implications

There are two theoretical implications in this study. First, this study's results indicate that service distribution (X1) has no and insignificant effect on customer loyalty (Y1). By Aaker (1996), brand awareness is the strength of a service distribution in the customers' minds. This strength is shown by customers' ability to recognize and remember a distribution service, which can also be assisted through associations carried out by the company, creating customer familiarity with distribution services, and showing commitment to customers' satisfaction. 
The second, service satisfaction (X2), positively and significantly affects customer loyalty (Y1). The level of customer awareness ranges from recognizing the brand, where the customer can realize a distribution service, to the level where distribution service is the dominant brand. Distribution service is the only thing that is remembered and becomes the identity of a product category. When making decisions, customers with full awareness become part of the consideration set to allow customer preferences to choose the distribution service product. Customers tend to use familiar distribution services because they feel safe with something known. Customers think that already known is likely to be reliable, and the quality can be accounted for.

The quality perception is: "customer's perception of the overall quality or superiority of a product or service concerning its intended purpose, relatives to alternatives" (Aaker, 1996). several aspects of dimensions distribution service quality: service performance, features, conformance to specifications, Reliability, durability, and serviceability. In certain product classes, essential dimensions can be seen directly by customers through an overall quality assessment. For example, many Automated Teller Machines (ATMs) in each location indicates that they can provide more effective service or cooperation with other financial institutions to conduct ATM service transactions. A positive impression of quality on customers' minds can offer various benefits to the development of distribution services, for example, creating a precise positioning and opening up opportunities for expansion of distribution services.

\section{Managerial Implications}

The results of this study provide managerial implications. This study found that Service Satisfaction has a positive influence on Customer Loyalty. Customer satisfaction can be generated by the Bank's performance, exceeding the desired customers' expectations for their service. Realizing customer satisfaction is not easy. People are now getting smarter and are starting to realize their rights, but by forming a good business strategy to ensure their survival. If customers feel that satisfaction, the services must simultaneously work with the trust value, so the value is significant. The excellent value will make customers feel satisfied, and in the end, the customers will be loyal to them.

Even though a bank's service quality is considered acceptable, their customers are not necessarily loyal. It turns out that customer loyalty to a bank's services does not always work with the Bank's services 
quality. The Bank that is considered capable of providing the best quality of service is BRISyariah bank.

\section{Social Implications}

First, suppose BRI Syariah managers' goal is to make their services image right through joint social responsibility (CSR). In that case, it is necessary to consider that this strategy will be more effective if they develop customer personalities related to emotional and social aspects, such as ethics, community support, environmentally responsible behavior, and fair treatment of employees. Besides, it is also important to consider functional factors such as facilities and service quality. Likewise, suppose managers want to increase customer loyalty through service images. In that case, it is necessary to design strategies related to the functional benefits of services such as facility design, room cleanliness, security, location, food, and beverages.

Second, it is necessary to encourage bank managers who aim to create a loyal customer base through initiatives of cooperate social responsibility (CSR) to design them through policies and strategies to communicate a responsible service image. These actions on customer attitudes will be practical only if done collectively and on an ongoing basis. Therefore, every Bank needs to communicate effectively in a social and environmental orientation for the customers as a Bank's target. To do this, bank managers can use different communication channels such as bank web pages or mass media to promote community initiatives in every dimension of cooperate social responsibility (CSR).

\section{Conclusion}

the conclusions based on the discussion above are first, the partial testing (t-test) on the Service Distribution variable of Automated Teller Machine (ATM) does not have a significant effect on the Service Loyalty of BRI Syariah sub-branch office (KCP) Pamekasan. This result follows the reality that there is only one Automated Teller Machine (ATM) unit located in the BRI Syariah Sub-Branch Office (KCP) Pamekasan.

Therefore, the customers have difficulty in withdrawing cash and using general services of ATM from their BRI Syariah account. Cash withdrawals made with other banks' ATMs, additional services cannot be done using the ATMs of other banks. Apart from cash withdrawals, banks have provided some benefits, namely interbank money transfers, top-ups, payments bills, and vouchers such as PDAM, electricity, phone credit, etc.

The ATM is also not complemented with a Cash Deposit feature that is 
commonly provided by other banks. Therefore, the customers who want to make cash deposits should queue to drive a manual warranty through BRI Syariah tellers. This manual deposit is slower in service speeds than using the Cash Deposit feature through an ATM.

The goodness of Fit based on RSquare shows that the Automated Teller Machine (ATM) Service Loyalty at the BRI Syariah KCP Pamekasan is $83.1 \%$. Indicates that these variables can explain the factors affecting Service Loyalty in this study by $83.1 \%$. In comparison, the remaining $16.9 \%$ is influenced by other variables not investigated in this study, such as products, prices, promotions, processes, people, and physical Forms. Which cannot be separated because the product, price, promotion, process, people, and physical Form are also part of the marketing mix in the Service of ATM at BRI Syariah.

\section{Limitation and Suggestions}

The researchers found some limitations. The first is the lack of respondents; the researchers found difficulty distributing the questionnaire to many respondents since it is incidental; the researcher only gives the questionnaire to the customers that come to the bank office. The second is the numbers of ATMs are limited. The ATM condition is also not equipped with the Cash Deposit feature, commonly provided by other banks. Therefore, if customers want to make a cash deposit, they have to queue to deposit manually through a BRI Syariah teller, which is slower than cash deposit via ATM from service speed.

Therefore, it is necessary to increase the number of ATMs and distribute them in all strategic locations in Pamekasan Regency. As a result, the community, especially BRI Syariah customers, can easily access these ATMs, and the level of customer satisfaction and loyalty will increase.

Based on this study's result, it is recommended to increase the number of Automated Teller Machines (ATMs) and distribute them in all strategic locations in Pamekasan District to the community and the BRI Syariah customers, in particular, can easily access this ATM. It will lead to an increase the customer satisfaction and loyalty level. It is recommended for the Bank to frequently provide promotions, establish MoU with several institutions, and promote the label of sharia possessed by the Bank. The customers are satisfied with the service of the Automated Teller Machine provided by BRI Syariah KCP Pamekasan. The next researcher is recommended to investigate other variables that are also part of the Automated Teller Machine (ATM). 
R. Agoes Kamaroellah, Anis Eliyana, Reza Mubarak, Service Distribution, and Service Satisfaction ...

\section{Reference}

Aaker, D. A. (1996). Measuring Brand Equity Across Products and Markets. California Management Review, $38(3)$.

Al Arif, N. R. (2010). Dasar-Dasar Pemasaran Bank Syariah. Bandung: Andi Offset.

Alma, B. (2007). Manajemen Pemasaran dan Pemasaran Jasa. Bandung: Alfabeta.

Arif, S. (2012). Pengaruh Kualitas Pelayanan Pengelolaan ATM Pada PT. SSI terhadap Kepuasan Nasabah BNI Pasuruan. Jurnal Ilmu \& Riset Manajemen, 1(11), 1-14.

Dewi, S. N., \& Nuzuli, T. (2017). Peran Promotional Mix sebagai Variabel Moderasi Orientasi Pelanggan dan Orientasi Pesaing terhadap Kinerja Pemasaran (Studi Empiris pada UKM Rumah Makan di Kabupaten Sragen). Ekuilibrium: Jurnal Ilmiah Bidang Ilmu Ekonomi, 12(2), 140-152.

Dharmmesta, B. S. (1999). Loyalitas pelanggan: Sebuah kajian konseptual sebagai panduan bagi peneliti. Journal of Indonesian Economy and Business, 14(3).
Farris, P. W., Bendle, N., Pfeifer, P., \& Reibstein, D. (2010). Marketing Metrics: The Definitive Guide to Measuring Marketing Performance. Pearson Education.

Foster, B. D., \& Cadogan, J. W. (2000). Relationship Selling and Customer Loyalty: An Empirical Investigation. Marketing Intelligence \& Planning, 18(4), 185-199.

Ismail, M. B. A. (2018). Manajeman Perbankan: Dari Teori Menuju Aplikasi. Kencana.

Kamus, T. P. (2007). Kamus Besar Bahasa Indonesia. Pusat Pembinaan dan Pengembangan Bahasa.

Karim, A. (2013). Adiwarman, Bank Islam: Analisis Fiqih dan Keuangan (Edisi Kelima). Jakarta: PT. Raja Grafindo Persada.

Kasmir. (2004). Pemasaran Bank. Jakarta: Kencana.

Kasmir. (2014). Manajemen Perbankan. Jakarta: PT. Raja Grafindo Persada.

Kasmir, B., \& Lainnya, L. K. (2014). DasarDasar Perbankan. Jakarta: PT. Raja Grafindo Persada. 
Kasmir, S. (2014). Bank dan Lembaga Keuangan Lainnya. Edisi Revisi. Depok: Rajawali Press.

Lam, S. Y., Shankar, V., Erramilli, M. K., \& Murthy, B. (2004). Customer value, satisfaction, loyalty, and switching costs: An illustration from a businessto-business service context. Journal of the Academy of Marketing Science, $32(3), 293-311$.

Lovelock, C., \& Wright, L. (2012). Jochen Wirtz dan Jacky Mussry. Pemasaran Jasa, Manusia, Teknologi, Strategi, Perpektif Indonesia. Jakarta: Penerbit Airlangga.

Nofinawati. (2016). Perkembangan Perbankan Syariah di Indonesia. JURIS (Jurnal Ilmiah Syariah), 14(2), 168-183. doi:

10.31958/juris.v14i2.305

Riyanto, R. P. (2015). Pengaruh Brand Image, Promosi dan Distribusi pada Keputusan Pembelian Sepeda Motor Honda Vario (Studi Kasus pada Konsumen Taruna Adiprima Motor Kudus) ( $\mathrm{PhD}$ Thesis). Universitas Negeri Semarang.

Sumar'in. (2012). Konsep Kelembagaan Bank Syariah. Bandung: Graha Ilmu.
Sumarni, M. (2011). Manajemen Pemasaran Bank. Yogyakarta: Liberty.

Supriyanto, E. B. (2003). Memaksimalkan Keuntungan dengan Loyalitas Nasabah. Infobank. Edisi, 286.

Syaipullah. (2011). Pengaruh Kemanfaatan Kartu ATM Terhadap Kepuasan Nasabah pada PT. Bank Mandiri Cabang Ahmad Yani Pekanbaru (Skripsi). Universitas Islam Negeri Sultan Syarief Kasim Riau.

Tjiptono, F., \& Chandra, G. (2016). Service, Quality dan Satisfaction Edisi 4. Yogyakarta: CV Andi Offset.

Yulianto, T. (2015). Pengaruh Kualitas Pelayanan ATM dan Kepercayaan Terhadap Kepuasan Nasabah (Studi Kasus pada Nasabah Bank BRI) (Skripsi). Universitas Muhammadiyah Surakarta. 